\title{
Effect of Different Chemical Preservatives on the Quality Attributes of Guava Aloe vera Blended Pulp at Ambient Conditions
}

\author{
Rehman Ullah Khan* and Muhammad Ayub
}

Department of Food Science and Technology, Faculty of Nutrition Sciences, The University of Agriculture, Peshawar, Khyber Pakbtunkhwa, Pakistan

Abstract | The present study was undertaken to examine the effect of chemical preservatives on physicochemical parameters $(\mathrm{pH}$, titratable acidity, total soluble solids, reducing sugar, non-reducing sugar and ascorbic acid), total phenolic compounds, total antioxidant capacity and sensory evaluation of guava aloe vera blended pulp. The treatments were as $\mathrm{GABP}_{0}$ (control), $\mathrm{GABP}_{1}(0.1 \% \mathrm{P} . \mathrm{S}), \mathrm{GABP}_{2}(0.1 \%$ K.M.S), GABP $_{3}(0.1 \%$ S.B $)$, GABP $_{4}(0.05 \%$ each P.S and K.M.S $)$, GABP $_{5}(0.05 \%$ each P.S and S.B $)$, GABP $_{6}(0.05 \%$ each K.M.S and S.B), GABP 7 (0.033\% each P.S+ KMS and SB). The guava aloe vera blended pulp samples of all treatments were packed in pet bottles and stored at ambient conditions for six months. The results revealed significant decline in $\mathrm{pH}$ from 4.51 to 3.47 , ascorbic acid from 120.42 to $51.48 \mathrm{mg} / 100 \mathrm{gm}$, total phenolic content from 32.43 to $11.47 \mathrm{mg}$ gallic acid equivalents $/ 100 \mathrm{~g}$ and antioxidant capacity from 76.02 to $33.23 \mathrm{TE} / 100 \mathrm{~g}$ while significant increase was observed in total soluble solids from 5.05 to $6.21^{\circ} \mathrm{Brix}$, total acidity from 0.62 to 1.11 during six months storage. Decline was revealed by all samples in sensory parameters. It was concluded that samples $\mathrm{GABP}_{6}$ and $\mathrm{GABP}_{7}$ showed maximum nutrients retention comparatively and remained highly acceptable during six months storage.

Received | March 18, 2020; Accepted | April 07,2020; Published | April 20, 2020

*Correspondence | Rehman Ullah Khan, Department of Food Science and Technology, Faculty of Nutrition Sciences, The University of Agriculture, Peshawar, Khyber Pakhtunkhwa, Pakistan; Email: Rehmanullahfst@yahoo.com

Citation | Khan, R.U. and M. Ayub. 2020. Effect of different chemical preservatives on the quality attributes of guava aloe vera blended pulp at ambient conditions. Sarbad Journal of Agriculture, 36(2): 411-418.

DOI | http://dx.doi.org/10.17582/journal.sja/2020/36.2.411.418

Keywords | (GABP) Guava aloe vera blended pulp, Physico-chemical, S.B (sodium benzoate), K.M.S (Potassium metabisulphite) and P.S (potassium sorbate)

\section{Introduction}

G uava (Psidium guajava) is one of the most glorious and nutritionally valuable fruit. Guava fruit made of 20\% peel, $50 \%$ flesh and 30\% seed core, Wilson (1980). It is famous owing to its low price, nutritional significance and pleasant aroma along with taste. It is grown on an area of sixty two thousand hectare giving total annual production of five hundred and twelve thousand tons and eight thousand two hundred and twenty three kilogram per hectare yield Hassan et al. (2012). Guava is a rich source of ascorbic acid, carbohydrates, proteins, minerals, pectin, calcium and phosphorus (Garget and Ruggoo, 2007). Guava is mainly utilized in fresh as a dessert fruit due to wonderful aroma, good nutritive profile and cheap availability in excess quantity during its peak season reflects high potential for processing into products, having both nutritional and health benefits. It's a best way for further utilization to prepare number of products from it like guava beverages, dehydrated products, jam and blended products with other fruits. The best way to reduce the post harvest losses is processing of surplus guava fruits into different 
products Bons et al. (2013).

Aloe vera plant has superb therapeutic uses. It is reported to be used in curing of diarrhoea, immune system regulation, tumors inhibition, liver protection, prevention of stomach from injury and repairing inner damage tissues etc. Aloe vera has diverse market potential Zhi et al. (2008). Leaves of aloe vera are rich source of vitamins, minerals, carbohydrates and amino acids. Human health is maintained by these aforementioned aloe vera leave constituents, Surjushe et al. (2008). Utilization of aloe vera pulp in food products has globally emerged a huge industry of functional food. Comparatively the functional products are rich source of biologically active compounds, Ramachandra et al. (2008). The blended beverage product may be a substitute refreshing nutritive drink and good source of bioactive compounds, vitamins and minerals, Sarkar and Jimmy (2017). The guava fruit and aloe vera contains important bioactive compounds and minerals. The preservation of guava aloe vera blended pulp will be helpful in minimizing the surplus yield and will fulfill requirements of functional food industry.

\section{Materials and Methods}

\section{Procurement of raw materials and samples preparation} Optimum matured guava fruits (Kohat variety) were procured locally. After sorting, the guava fruits were thoroughly washed, the Pulp was obtained by using pulper machine. Fully expanded, mature, healthy and fresh leaves of aloe vera were picked from aloe vera orchard in PCSIR Peshawar. After washing, the outer skin of leaves was removed using sharp stainless steel knife and the obtained inner gel was blended in blender machine to obtain its pulp. The guava and aloe vera pulp was mixed in different proportions (90:10, 80:20, 70:30, 60:40 and 50:50) and sensory evaluation was conducted for selection of best suitable blend. The maximum score of judges was secured by (70:30) blend of guava and aloe vera pulp.

\section{Plan of study}

The treatments were prepared as $\mathrm{GABP}_{0}$ (control), $\mathrm{GABP}_{1}$ (0.1\% Potassium Sorbate), GABP $2(0.1 \%$ potassium metabisulphite), $\mathrm{GABP}_{3}(0.1 \%$ sodium benzoate), $\mathrm{GABP}_{4}(0.05 \%$ each potassium sorbate and potassium metabisulphite), $\mathrm{GABP}_{5}(0.05 \%$ each potassium sorbate and sodium benzoate), $\mathrm{GABP}_{6}$ (0.05\% each sodium benzoate and potassium meta bisulphite), $\mathrm{GABP}_{7}(0.033 \%$ each potassium sorbate, sodium benzoate and potassium metabisulphite).

\section{Packaging and storage}

The treatments of guava aloe vera blended pulp samples of all treatments were packed in $300 \mathrm{ml}$ pet bottles and stored at ambient conditions for six months.

\section{Physico-chemical and sensory evaluation}

The samples of guava and aloe vera blended pulp were evaluated for physico-chemical analysis including $\mathrm{pH}$, percent acidity, total solids, complete sugar profile and ascorbic acid by the methods of AOAC (2012). Phenolic contents were determined by the spectrophotometric method of Sadasivam and Manicam (2008). The total antioxidant capacity was calculated by radical scavenging influence on the DPPH free radical by Goupy et al. (1999) and sensory evaluation including color, flavor and overall acceptability by nine points hedonic scale (Larmond, 1977). Analysis of the blended pulp samples were conducted after each month during six months study.

\section{Statistical analysis}

The data was analyzed statistically by using two fatorial Complete Randomized Design (CRD), and LSD test was employed for means separation at 0.05\% significant level by (Steel and Torrie, 1997).

\section{Results and Discussion}

\section{pH and titeratable acidity}

The data of $\mathrm{pH}$ revealed decrease in all guava aloe vera blended pulp samples at ambient conditions. Mean value of $\mathrm{pH}$ at ambient temperature decreased from 4.51 to 3.47 during six months. The decrease in $\mathrm{pH}$ of treatments were as sample $\mathrm{GABP}_{0}$ from (4.50 to 1.28$), \mathrm{GABP}_{1}$ (4.51 to 3.72$), \mathrm{GABP}_{2}$ (4.52 to 3.84 ), $\mathrm{GABP}_{3}$ (4.50 to 3.80 ), $\mathrm{GABP}_{4} 4.52$ to $3.73, \mathrm{GABP}_{5} 4.51$ to $3.83, \mathrm{GABP}_{6}(4.50$ to 3.78$)$ and $\mathrm{GABP}_{7}(4.51$ to 3.75$)$ respectively. The highest mean value for treatment was noted for sample $\mathrm{GABP}_{2} 4.26$ chased by $\mathrm{GABP}_{6} 4.21$ while the sample $\mathrm{GABP}_{0}$ gives minimum mean value 2.79 followed by $\mathrm{GABP}_{1} 4.12$ (Figure 1). All values for $\mathrm{pH}$ of guava aloe vera blended pulp were significantly different at $(p<0.05)$. The increment in acidity of preserved guava pulp during storage period was due to organic acids generation. Break down of pectin and development of free radical might be associated for this decline in pH, Bal et al. (2014). Present study was in line with 
Ahmad et al. (2000), who observed that decrease in $\mathrm{pH}$ of guava pulp during storage.

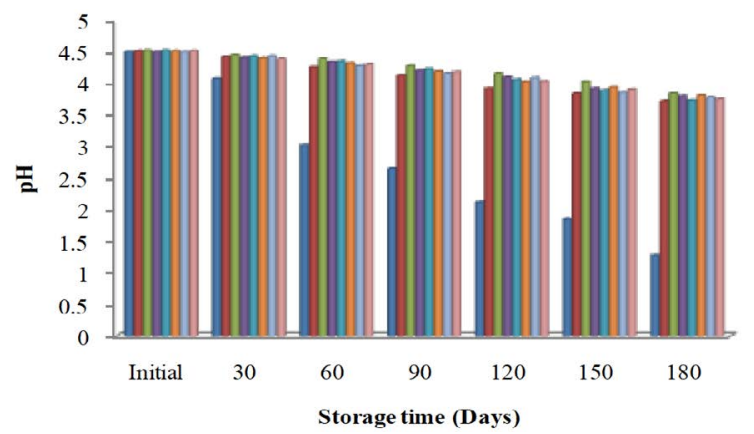

GABP0

- GABP1

GABP2

- GABP3

GABP4

GABP6

- GABP7

Figure 1: Effect of different chemical preservatives on $p H$ of guava aloe vera blended pulp at ambient condition.

Values followed by different letters are significantly ( $p \leq 0.05)$ different from each other.

The titratable acidity of guava aloe vara blended pulp samples was enhanced. The acidity of sample $\mathrm{GABP}_{0}$ was increased from 0.62 to 2.14 , GABP 0.61 to $0.98, \mathrm{GABP}_{2} 0.62$ to $0.99, \mathrm{GABP}_{3} 0.62$ to $0.95, \mathrm{GABP}_{4} 0.62$ to $0.93, \mathrm{GABP}_{5} 0.62$ to $0.95, \mathrm{GABP}_{6} 0.63$ to 0.97 and $\mathrm{GABP}_{7}$ increased from 0.61 to 0.94 . The highest increase in mean value was leaded by sample $\mathrm{GABP}_{0} 1.31$ chased by $\mathrm{GABP}_{1} 0.81$. The least mean was recorded by sample $\mathrm{GABP}_{4} 0.76$ succeeded by $\mathrm{GABP}_{2} 0.77$ (Figure 2). All values for titratable acidity of guava aloe vera blended pulp were significantly different at $(\mathrm{p}<0.05)$. These finding is supported by Kinh et al. (2001), who noted increase in acidity of apple pulp. The outcomes of also confirm our results who claimed enhancement in acidity and decline in $\mathrm{pH}$ of apricot pulp during storage.

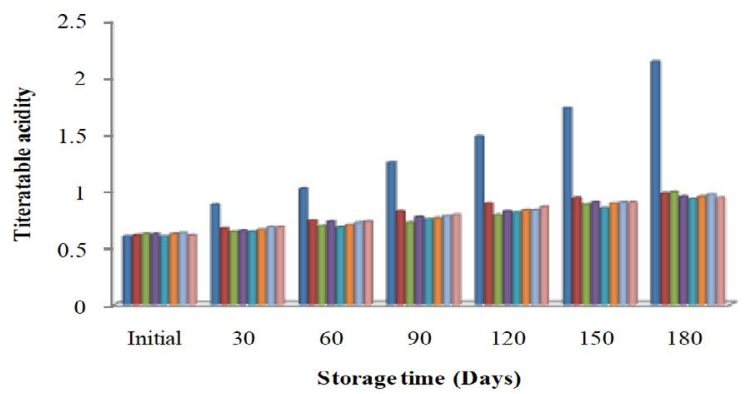

- GABPO

- GABP1

GABP2

GABP3

GABP5

$=\mathrm{G} \wedge \mathrm{BP} 6$

aABP7

Figure 2: Effect of different chemical preservatives on \% acidity of guava aloe vera blended pulp at ambient conditions.

Values followed by different letters are significantly $(p \leq 0.05)$ different from each other.

Total soluble solids, reducing and non reducing sugar

Total soluble solids of guava aloe vera blended pulp samples were raised at ambient temperature from 5.05 to 6.21. The total soluble solids of control sample was reduced from $\mathrm{GABP}_{0}$ (5.05 to 1.07) while increase was observed in $\mathrm{GABP}_{1}$ (5.04 to 6.45), $\mathrm{GABP}_{2}(5.05$ to 6.94), $\mathrm{GABP}_{3}$ (5.05 to 7.08), $\mathrm{GABP}_{4}$ (5.06 to 7.06), $\mathrm{GABP}_{5}(5.05$ to 6.98$), \mathrm{GABP}_{6}(5.02$ to 6.95$)$ and $\mathrm{GABP}_{7}(5.04$ to 7.14$)$ during 180 days study (Figure 3). Lead in treatments means was attained by $\mathrm{GABP}_{6}(6.16)$ runner up by $\mathrm{GABP}_{6}(6.08)$ whereas the lowest mean value was acquired by treatment $\mathrm{GABP}_{0}$ (3.33) followed by $\mathrm{GABP}_{1}$ (5.74). All values for total soluble solids of guava aloe vera blended pulp were significantly different $(\mathrm{p}<0.05)$. The finding of Suman et al. (2017) support our data, who stated that total soluble solids of stored guava pulp was increased with the advancement in storage. The increment in TSS content of preserved guava pulp during storage was probably due to conversion of free polysaccharides (starch) into monosaccharide Jain et al. (2007). Another study of Kumar et al. (2015), also confirmed our results as they stated increase trend in total soluble solids during storage.

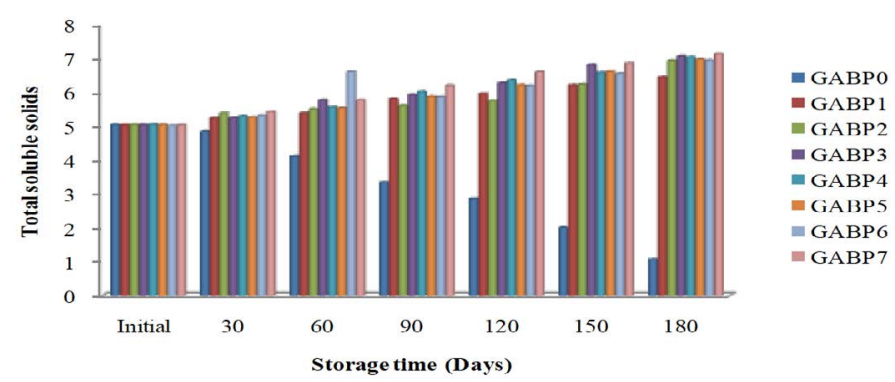

Figure 3: Effect of different chemical preservatives on total soluble solids of guava aloe vera blended pulp at ambient conditions.

Values followed by different letters are significantly ( $p \leq 0.05$ ) different from each other.

At room temperature the reducing sugars of guava aloe vera blended pulp samples were enhanced from 3.54 to 3.73 during six months of storage period. Reducing sugar of sample $\mathrm{GABP}_{1}$ was increases from (3.52 to 4.02), $\mathrm{GABP}_{2}$ (3.55 to 4.03), $\mathrm{GABP}_{3}$ (3.53 to 4.08), $\mathrm{GABP}_{4}$ (3.54 to 4.16), $\mathrm{GABP}_{5}(3.55$ to 4.18$), \mathrm{GABP}_{6}$ (3.53 to 4.12 ) and $\mathrm{GABP}_{7}$ (3.54 to 4.19) during shelf life of 180 days studies respectively (Figure 4). The lead in mean value was attained by the sample $\mathrm{GABP}_{7}$ (3.91) followed by $\mathrm{GABP}_{5}$ (3.87) whereas the lowest mean value was retained by $\mathrm{GABP}_{0}$ (2.06) succeeded by $\mathrm{GABP}_{2}$ (3.76). All values for reducing sugars of guava aloe vera blended pulp were significantly different at $(\mathrm{p}<0.05)$. Desai et al. (2012) stated the similar results, who claimed increase in reducing sugar mango pulp. Suman et al. (2017) also lay down similar increase in sugar profile. Complex carbohydrates like hemicelluloses and other saccharides into simple soluble sugars might be responsible for this change. 


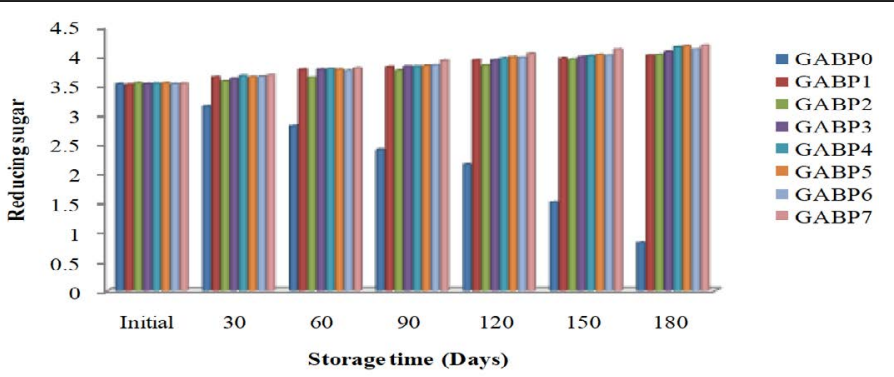

Figure 4: Effect of different chemical preservatives on reducing sugar of guava aloe vera blended pulp at ambient conditions. Values followed by different letters are significantly ( $p \leq 0.05$ ) different from each other.

The guava aloe vera blended pulp samples showed decrease in non-reducing sugars at room temperature $\mathrm{GABP}_{0}$ from (1.47 to 1.0$)$, $\mathrm{GABP}_{1}$ (1.48 to 0.98 ), GABP $_{2}(0.81$ to 0.97$), \mathrm{GABP}_{3}(1.47$ to 0.92$)$, $\mathrm{GABP}_{4}$ (1.46 to 0.84$), \mathrm{GABP}_{5}$ (1.45 to 0.82$), \mathrm{GABP}_{6}$ (1.47 to 0.88$)$ and $\mathrm{GABP}_{7}(1.46$ to 0.81$)$ respectively during 180 days of its shelf life studies (Figure 5). The highest mean was acquired by $\mathrm{GABP}_{2}$ (1.24) followed by $\operatorname{GABP}_{1}(1.19)$ whereas the least value was retained by sample $\mathrm{GABP}_{0}(0.85)$ succeeded by $\mathrm{GABP}_{7}$ (1.10). All values for non-reducing sugars of guava aloe vera blended pulp were significantly different at $(p<0.05)$. Findings of Durrani et al. (2016) are in line with our data, who find decrease in non reducing sugar of mango pulp which is associated with degradation of complex sugars and formation of simple carbohydrates. Reddy et al. (2006) and Tefera et al. (2008) also revealed changes in sugar profile.

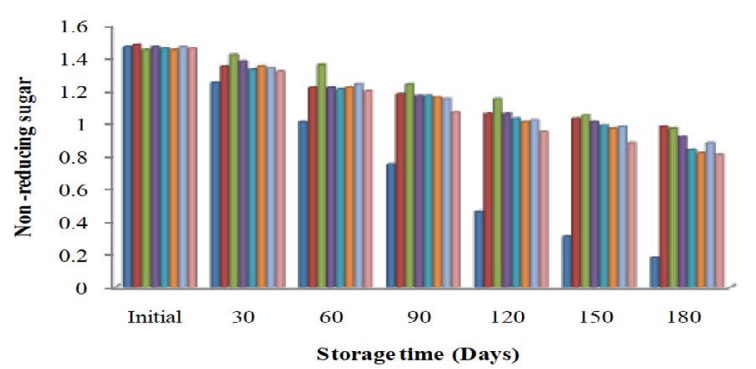

$=\mathrm{GABP} 0$ GABP1 GABP3 GABP4 GABP5 GABP6 $=\mathrm{GABP} 7$

Figure 5: Effect of different chemical preservatives on non-reducing sugar of guava aloe vera blended pulp at ambient conditions.

Values followed by different letters are significantly $(p \leq 0.05)$ different from each other.

\section{Ascorbic acid}

The guava aloe vera pulp samples showed decline in ascorbic acid content during six months storage stability studies at ambient temperature. The ascorbic acid was reduced from 120.42 to $51.48 \mathrm{mg} /$ $100 \mathrm{gm}$. During stability studies of guava aloe vera pulp samples for six months, the ascorbic acid was reduced as $\mathrm{GABP}_{0}$ from (121.80 to 2.17), $\mathrm{GABP}_{1}$ (120.41 to 60.84$), \mathrm{GABP}_{2}$ (120.20 to 58.95), GABP
(120.20 to 65.48), $\mathrm{GABP}_{4}(120.20$ to 56.85$), \mathrm{GABP}_{5}$ (120.15 to 55.79), $\mathrm{GABP}_{6}(120.08$ to 53.89) and $\mathrm{GABP}_{7}(120.04$ to 57.78$)$ (Figure 6). The treatment $\mathrm{GABP}_{3}$ achieved highest mean value (93.66) followed by $\mathrm{GABP}_{1}(88.22)$ while sample $\mathrm{GABP}_{0}$ retained the lowest value (46.38) succeeded by $\mathrm{GABP}_{6}$ (85.51). All values for ascorbic acid of guava aloe vera blended pulp were significantly different at $(\mathrm{p}<0.05)$. Yadve et al. (2017) claimed decrease in ascorbic acid of guava pulp. Decline was occurred by degradation of ascorbic acid by enzymes. The findings of Bons et al. (2011) also assured our data of ascorbic acid.

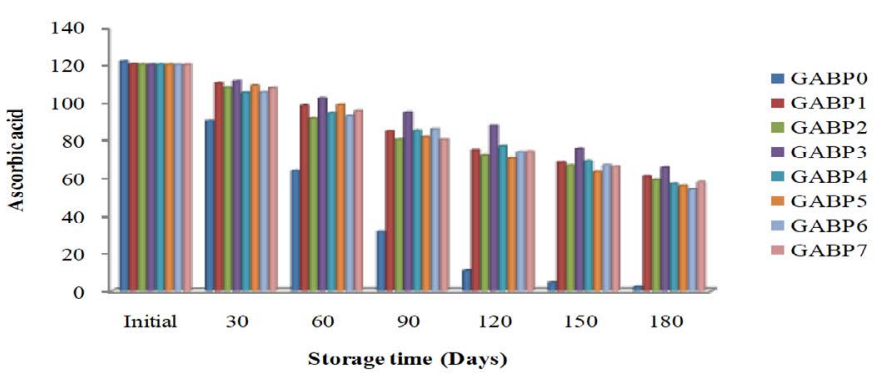

Figure 6: Effect of different chemical preservatives on ascorbic acid of guava aloe vera blended pulp at ambient conditions.

Values followed by different letters are significantly ( $p \leq 0.05$ ) different from each other.

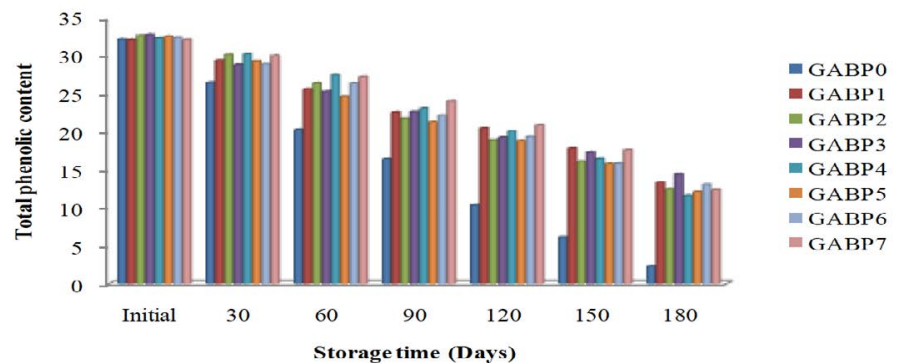

Figure 7: Effect of different chemical preservatives on total phenolic compound of guava aloe vera blended pulp at ambient conditions. Values followed by different letters are significantly $(p \leq 0.05)$ different from each other.

\section{Total phenolic compounds}

Guava aloe vera blended pulp samples responded decrease in total phenolic compounds ( $\mathrm{mg}$ gallic acid equivalents $/ 100 \mathrm{~g}$ ) at ambient temperature during storage of six months. The total phenolic compounds were reduced from 32.43 to $11.47 \mathrm{mg}$ gallic acid equivalents $/ 100 \mathrm{~g}$. The treatments showed the decrease as $\mathrm{GABP}_{0}$ from (32.20 to 2.31), $\mathrm{GABP}_{1}$ (32.15 to 13.36), $\mathrm{GABP}_{2}$ (32.68 to 12.47$), \mathrm{GABP}_{3}(32.82$ to 14.42), $\mathrm{GABP}_{4}$ (32.36 to 11.59$), \mathrm{GABP}_{5}$ (32.57 to 12.14), $\mathrm{GABP}_{6}(32.43$ to 13.05$)$ and $\mathrm{GABP}_{7}(32.19$ to 12.38) (Figure 7). Maximum mean value for treatment was revealed by $\mathrm{GABP}_{7}$ (24.51) followed by $\operatorname{GABP}_{6}(23.21)$ while $\mathrm{GABP}_{0}$ retained minimum mean value (16.89) followed by $\mathrm{GABP}_{1}$ (20.07). All June 2020 | Volume 36 | Issue 2 | Page 414 
values for total phenolic compound of guava aloe vera blended pulp were significantly different at $(p<0.05)$. The present reduction of phenolic compounds are in accordance with Cansino et al. (2013) and Kapoor and Ranote (2016) who reported significant decline in phenolic content during storage period. phenolic compounds are volatile in nature, which were reduced in storage, (Ranganna, 1986).

\section{Antioxidant capacity}

All samples of guava aloe vera blended pulp showed decrease in antioxidant at storage of ambient conditions. Mean value was decreased from 32.08 to 19.14 during period of six months. The decrease in treatments was $\mathrm{GABP}_{0}$ from (75.50 to 6.52), GABP (76.23 to 31.52$), \mathrm{GABP}_{2}$ (75.76 to 35.11 ), $\mathrm{GABP}_{3}$ (75.41 to 37.74$), \mathrm{GABP}_{4}$ (76.14 to 33.05$), \mathrm{GABP}_{5}$ (76.06 to 42.21), $\mathrm{GABP}_{6}$ (75.89 to 39.41) and $\mathrm{GABP}_{7}(76.09$ to 41.56$)$ respectively (Figure 8). The sample $\mathrm{GABP}_{7}$ achieved highest mean value (60.44) followed by $\mathrm{GABP}_{6}$ (58.65) while sample $\mathrm{GABP}_{0}$ attained lowest mean value (33.05) chased by $\mathrm{GABP}_{1}$ (50.15). All values for antioxidant capacity of guava aloe vera blended pulp were significantly different at $(p<0.05)$. These finding are confirmed by Prabal et al. (2018) who documented significant reduction in antioxidant capacity during 60 days. These results are also in line with Hoffmann et al. (2017) who recorded fifty percent decline in antioxidant capacity in buti fruit pulp and nectar during storage.

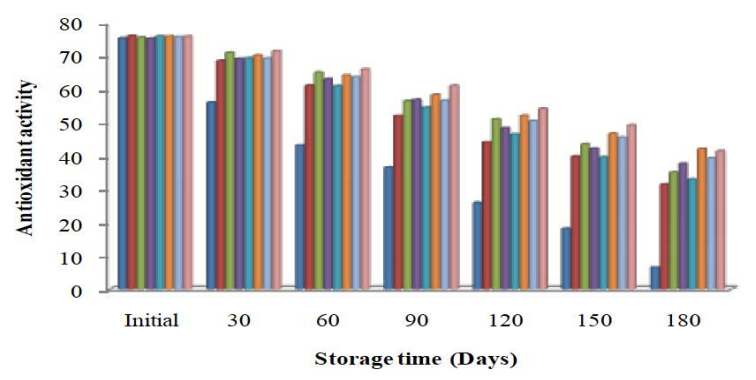

- GABPo - GABP1 GABP2 GABP3 GABP4 GABP6 GABP7

Figure 8: Effect of different chemical preservatives on antioxidant cap. of guava aloe vera blended pulp at ambient conditions.

Values followed by different letters are significantly ( $p \leq 0.05$ ) different from each other.

\section{Sensory evaluation}

Color: Sensory evaluation is an important aspect for the analyzing the quality of food products. The mean score for color of guava aloe vera blended nectar was decreased from 9.00 to 5.73. The reduction in treatments mean value for color was $\mathrm{GABP}_{0}$ from (9.00 to 1.00$), \mathrm{GABP}_{1}$ (9.00 to 4.46$), \mathrm{GABP}_{2}(9.00$ to 7.37$), \mathrm{GABP}_{3}(9.00$ to 5.52$), \mathrm{GABP}_{4}(9.00$ to 5.85), $\mathrm{GABP}_{5}(9.00$ to 6.21$), \mathrm{GABP}_{6}(9.00$ to 6.63 ) and $\mathrm{GABP}_{7}$ (9.00 to 6.74) respectively. The sample
$\mathrm{GABP}_{7}$ and $\mathrm{GABP}_{2}$ attained the maximum mean value (8.08) followed by $\mathrm{GABP}_{5}$ (8.02) while lowest mean was noted for $\mathrm{GABP}_{0}$ (3.94) chased by GABP (7.25) (Figure 9). All values for color of guava aloe vera blended pulp were significantly different at $(p<0.05)$. This decline in data was supported by Kumari (2016), who reported decline in color. Yadav et al. (2017) also claimed similar reduction in color of guava pulp.

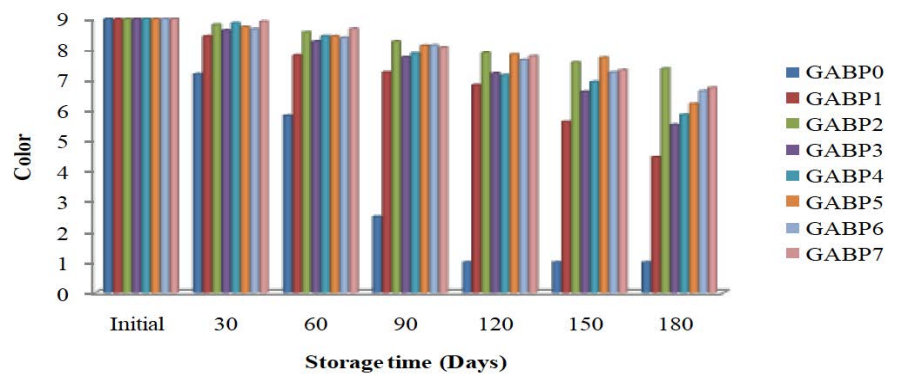

Figure 9: Effect of different chemical preservatives on color of guava aloe vera blended pulp at ambient conditions.

Values followed by different letters are significantly $(p \leq 0.05)$ different from each other.

Taste: The mean value for taste of guava aloe vera blended pulp samples at room temperature were decreased from 8.85 to 4.90 . The decrease in mean value for treatments was recorded as $\mathrm{GABP}_{0}$ from (8.80 to 1.00$), \mathrm{GABP}_{1}$ (8.90 to 3.58), $\mathrm{GABP}_{2}$ (8.85 to 5.81$), \mathrm{GABP}_{3}(8.80$ to 4.62$), \mathrm{GABP}_{4}$ (8.88 to 5.26), $\mathrm{GABP}_{5}(8.85$ to 6.48$), \mathrm{GABP}_{6}(8.80$ to 6.25$)$ and $\mathrm{GABP}_{7}(8.85$ to 6.13 ) respectively (Figure 10). Highest mean value was acquired by treatment $\mathrm{GABP}_{5}$ (7.74) followed by $\mathrm{GABP}_{6}$ (7.64) while the treatment $\mathrm{GABP}_{0}$ (3.36) chased by $\mathrm{GABP}_{1}$ (6.28). All values for taste of guava aloe vera blended pulp were significantly different at $(\mathrm{p}<0.05)$. These findings were accordance with Rafia et al. (2018) who recorded decline trend in taste for guava ready to serve beverage. Another conclusion of Pandey (2004) also supported our results who found similar decreasing trend for taste in product of guava.

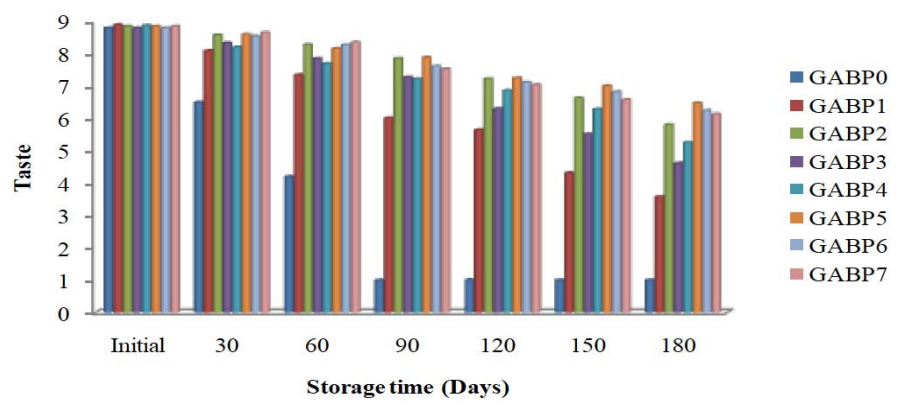

Figure 10: Effect of different chemical preservatives on taste of guava aloe vera blended pulp at ambient conditions.

Values followed by different letters are significantly $(p \leq 0.05)$ different from each other. 
Overall acceptability: The overall acceptability of guava aloe vera blended pulp was reduced at ambient temperature from 8.96 to 5.06. The mean score for treatments were reduced $\mathrm{GABP}_{0}$ from (8.95 to 1.00), $\mathrm{GABP}_{1}$ (8.91 to 4.03), $\mathrm{GABP}_{2}$ (9.00 to 6.01), GABP (8.90 to 5.64), $\mathrm{GABP}_{4}$ (9.00 to 4.95$), \mathrm{GABP}_{5}(8.95$ to 6.15$), \mathrm{GABP}_{6}(8.94$ to 6.27$)$ and $\mathrm{GABP}_{7}(9.00$ to 6.35) respectively (Figure 11 ). The $\mathrm{GABP}_{7}$ attained the maximum mean score $(7.87)$ chased by $\mathrm{GABP}_{6}$ (7.81) while minimum score was achieved by $\mathrm{GABP}_{0}$ (4.51) followed by $\mathrm{GABP}_{1}$ (7.18). All values for overall acceptability of guava aloe vera blended pulp were significantly different at $(\mathrm{p}<0.05)$. Shahnawaz et al. (2012) stated similar decline in overall acceptability of mango sea buckthorn blended pulp during storage. Likewise, observations were recorded by Saeed et al. (2010). Khurshid and Zeb (2008) also reported the decrease in overall acceptability of low caloric apple drink during refrigerated storage.

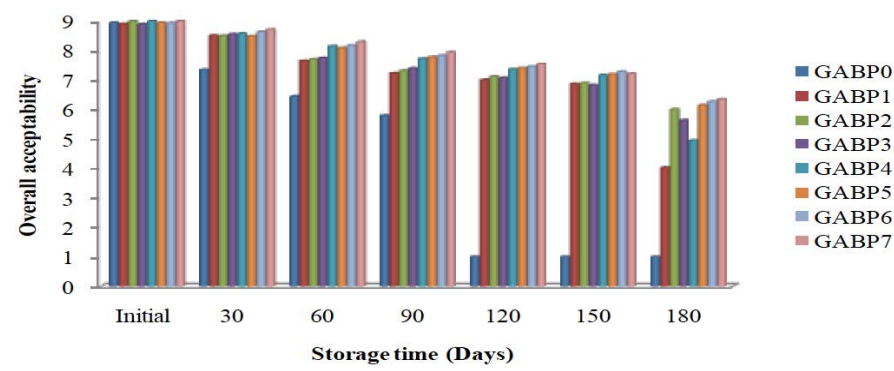

Figure 11: Effect of different chemical preservatives on overall accep. of guava aloe vera blended pulp at ambient conditions.

Values followed by different letters are significantly ( $p \leq 0.05$ ) different from each other.

\section{Conclusions and Recommendations}

The data obtained of all parameters depicted that the treatments $\mathrm{GABP}_{6}$ and $\mathrm{GABP}_{7}$ showed comparatively better nutrient retention and secured higher overall acceptability till six months storage at ambient temperature. Moreover, application of preservatives in combination was more effective in enhancing the shelf life of guava aloe vera blended pulp. It is recommended that such kind of studies may also be established at controlled temperature conditions.

\section{Novelty Statement}

For first time, blended guava aloe vera pulp was developed. The incorporation of aloe vera pulp significantly enhanced the nutritional composition of blended pulp.

\section{Author's Contribution}

Rehman Ullah Khan: Conceived the basic idea, data collection, data entry and analysis and write-up the manuscript.

Muhammad Ayub: Supervised the research, helped in designing the study and also provided technical input in writing and improving the manuscript.

\section{References}

Ahmad, I., R. Khan and A. Muhammad. 2000. Effect of added sugar at various concentrations on the storage stability of guava pulp. Sarhad J. Agric., 16(1): 89- 93.

AOAC, 2012. Official methods of analysis of the association of official analytical chemists, $19^{\text {th }}$ ed., pp. 1058-1059.

Ayub, M., T. Durrani, A. Zeb and J. Ullah. 2007. Effect of sucrose and potassium metabisulphite on the physicochemical and microbial analysis of apricot pulp. Pak. J. Sci. Ind. Res. 50(4): 251253

Bal, L.M., T.Ahmad, A.K. Senapati and P.S. Pandit. 2014. Evaluation of quality attribute during storage of guava nectar cv. Lalit from different pulp and TSS ratio. J. Food Proc. Technol., 5(5): 329-334.

Bons, P.D., D. Jansen, F., Mundel, C.C., Bauer, T., Binder and O. Eisen. 2011. Response of guava pulp during storage ambient conditions. Nature Commun. 7(1): 11-27

Bons, H.K. and S.S. Dhawan. 2013. Studies on preservation of guava pulp. Indian J. Hortic., 70(3): 452-454.

Cansino, N.C., G.P. Carrera, Q.Z. Rojas, L.D. Olivares, E.A. García and E.R. Moreno. 2013. Ultrasound processing on green cactus pear (Opuntia ficus Indica) juice: physical, microbiological and antioxidant properties. J. Food Process. Technol. 1: 4-9.

Desai, C.S., A.K. Naik and J.M. Patil. 2012. Study on physiochemical properties of some early mango (Mangiferaindica L) varieties for pulp processing. Beverages Food World, 39(2): 5557.

Durrani, Y., A.Zeb, S.A.Ali, N.U. Khan,J.Hussain, T.A. Naqvi and T. Ahmed. 2016. Effects of chemical preservatives on mango squash stored under different temperature regimes. Minerva Biotecnol., 28(3): 153-158. 
Garget, D.G. and A. Ruggoo. 2007. Effect of processing and storage of guava into jam and juice on the ascorbic acid content. J. Plant Nutri. 58: 1-12.

Goupy, P., M. Hgues, P. Bovin and M.J. Amiot. 1999. Antioxidant composition and activity of barley (Hordeum vugare) and malt extracts of isolated phenolic compounds. J. Sci. Food Agric., 79: 1625-1634.https://doi.org/10.1002/ (SICI)1097-0010(199909)79:12<1625::AIDJSFA411>3.0.CO;2-8

Hassan, I., W. Khurshid and K. Iqbal. 2012. Factors responsible for decline in guava (Psidium guajava) yield. J. Agric. Res., 50(1): 129-134.

Hoffmann, J.F., G.P. Zandona, P.S.D. Santos, C.M. Dallmann, F.B. Madruga, C.V. Rombaldi and F.C. Chaves. 2017. Stability of bioactive compounds in Butia (Butia Odorata) fruit pulp and nectar. Food Chem., 237: 638-644. https:// doi.org/10.1016/j.foodchem.2017.05.154

Jain, P.K. and P.K. Nema. 2007. Processing of pulp of various cultivars of guava (Psidiumguajava L.) for leather production. Agric. Eng. Int. Int. Counc. Large Electr. Syst., 9: 1-9.

Kapoor, S. and P.S. Ranote. 2016. Antioxidant components and physico-chemical characteristics of jamun powder supplemented pear juice. J. Food Sci. Technol., 53(5): 23072316. https://doi.org/10.1007/s13197-0162196-x

Kinh, S.A.E.H., C.P. Dunne and D.G. Hoover. 2001. Preparation and preservation of apple pulp with chemical preservatives and mild heat. J. Food Prot. 28(6): 111- 114

Khurshid, A. and A. Zeb. 2008. Preparation and quality analysis of low caloric apple drink. Thesis. Dept. Food Sci. Tech. Univ. Agric. Peshawar.

Kumar,M., R.K. Godara, D. Singh, D.V.Pathak and S. Singh. 2015. Effect of different preservatives on the storage of ber pulp. Int.J. Farm Sci., 5(4): 222- 228.

Kumari, Y. 2016. Studies on effect of blending impact of guava (Psidium guajava $\mathrm{L}$ ) and papaya (Carica papaya L) pulp on recipe standardization of blended nectar and RTS (ready to serve) beverages. M. Sc. (Hort) thesis. Dept. Fruit Sci. Indira Gandhi Krishi Vishwavidyalaya Raipur.

Larmond, E. 1997. Laboratory method of sensory evaluation of food. Publication 1977, Can. Deptt. Agric. Ottawa. No.95/2/EC on food additives other than colours and sweeteners. Europ. Parliament and Council Directive (1995).

Pandey, A.K. 2004. Study about the storage stability of guava beverages. Prograessive Hortic. 36(10): 142-145.

Prabal, P.S., A.D. Tripathi, D.C. Rai, N. Kumar and U.P. Singh. 2018. To study the shelf life of Aloe vera fortified mango RTS with different time and temperature combinations on its organoleptic and functional properties. Pharm. Innov. J. 7(3): 91-97.

Rafia, R., A. Bhat, A. Dayal,M. Sood and S. Sharma. 2018. Studies on storage stability of guava RTS. Pharm. Innov. J. 7(5): 230-233.

Ramachandra, C.T. and P.S. Rao. 2008. Processing of aloe vera leaf gel. Rev. Am. J. Agric. Boil. Sci., 3(2): 502-510. https://doi.org/10.3844/ ajabssp.2008.502.510

Ranganna, S., 1986. Handbook of analysis and quality control for fruit and vegetable products, $2^{\text {nd }}$ edn. Tata McGraw Hills Publ Co. Ltd, New Delhi.

Reddy, L.V.A. and O.V.S. Reddy. 2006. Production and characterization of wine from mango fruit (Mangifera indica L). World J. Micro. Biotech. 21(13): 45-50.

Sadasivam, S. and A. Manickam. 2008. Biochemical methods, $3^{\text {rd }}$ Edn, New Age Int. (P) Limited Publ., pp. 203-206.

Saeed A., M. Riaz, A. Ahmad and A. Nisar. 2010. Physico-chemical, microbiological and sensory stability of chemically preserved mango pulp. Pak. J. Bot. 42(2): 853-862

Sarkar, A. and B. Jimi. 2017. Standardization of blending of guava pulp with pineapple juice for preparation of Ready-To-Serve (RTS). Int. J. Curr. Microbiol. App. Sci., 6(11): 395-401. https://doi.org/10.20546/ijcmas.2017.611.045

Shahnawaz, M., A. Wali, Y. Durrani, M. Ayub, A. Muhammad, M.R. Khan and H. Khan. 2012. Refrigerated storage studies of mango seabucthorn blended pulp with selective chemical preservatives and ginger extract. Int. J. Food Nut. Sci., 1(1): 01-07.

Steel, R.G.D. and J.H. Torrie. 1997. Principles and procedures of statistics. McGraw Hill Book Co. New York. Stat. Proc. Agric. Res. (2 $\left.2^{\text {nd }} E d\right) . p p$. 8-22.

Surjushe, A., R. Vasani and D.G. Saple. 2008. Aloe vera: a short review., Indian J. Dermatol. 
53(4): 163-166. https://doi.org/10.4103/00195154.44785

Suman, K.Y., D.K. Sarolia, S. Pilania, H.R. Meena and L.N. Mahawer. 2017. Studies on keeping quality of preserved guava pulp during storage. Int.J. Curr.Microbiol.App. Sci.6(3): 1235-1242. https://doi.org/10.20546/ijcmas.2017.603.142

Tefera, A., T. Seyoum and K. Woldesadik. 2008. Effects of disinfection packaging and evaporatively cooled storage on sugar content of mango. Afr. J. Biotech. 7: 65-72.

Wilson, C.W., 1980. Tropical and Sub-tropical Fruits: composition, properties and uses. AVI Publ. Inc. West Port Connecticut, 25(2): 279295.

Yadav, S.K., D.K. Sarolia, S. Pilania, H.R. Meena and L.N. Mahawer. 2017. Studies on keeping quality of preserved guava pulp during storage. 2017. Int. J. Curr. Microbiol. App. Sci. 6(3): 1235-1242. https://doi.org/10.20546/ ijcmas.2017.603.142

Zhi, L., Z.J. Ling and Y.Z. Wen. 2008. Study of a compound juice made of aloe and apple. Fruit Proc. 18(6): 312-314. 